\title{
COMPENSATION IN RESIDENTIAL REAL ESTATE PURCHASERS' DECISIONS
}

\author{
Alina Źróbek-Różańska \\ Department of Economic and Regional Policy \\ University of Warmia and Mazury \\ e-mail:alina.zrobek@uwm.edu.pl
}

\begin{abstract}
Predicting demand on the residential real estate market and the behavior of the purchasers requires a wide knowledge of both the economic mechanisms and psychology of decision-making. Decisions on the real estate market are often made by people without professional skills, and using simplified strategies. However, the decision-making process, on top of its heuristic nature, is dynamic and changing. As a result, a discrepancy in the preferred characteristics of planned and actually bought real estate can be observed. Such a discrepancy can be explained with the occurrence of the compensation process. The aim of this article was to recognize and describe the compensation process on the example of the suburban residential real estate market. The aim was achieved by analyzing the preferences of potential buyers in terms of particular characteristics of the location of suburban plots destined for single-family housing (respondents divided into age groups: 25 and 26-40), analyzing the real settlement trend in the suburban zone (the result of actual transactions) and comparing the results, including compensation.
\end{abstract}

Key words: decision, compensation, real estate market.

JEL Classification: D120, R30.

Citation: Źróbek-Różańska A., 2016, Compensation in Residential Real Estate Purchasers' Decisions, Real Estate Management and Valuation, vol. 24, no. 4, pp. 70-78.

DOI: $10.1515 /$ remav-2016-0031.

\section{Introduction and literature review}

The real estate market is a specific market, relatively less transparent and worse organized than others (KUCHARSKA-STASIAK 2002, p. 38). It cannot be described as a normal market, as general characteristics of a normal market are substitutability, limitation, ability to be the object of investment, or lack of distortions from the transaction costs. Meanwhile, on the real estate market, substitutability is strongly limited, which results from immobility and the dominating impact of location (absolute and relative); limitation is significant (supply cannot immediately react to an increase in demand), which results from, e.g. the very nature of the investment process, and costs accompanying transactions are often very high (ALEXANDER 2014). Special attention should also be paid to the investors acting on the real estate market. First, real estate as an investment asset is quite similar to the assets on the financial market. In these cases investors acquire property not for its use-value, but for an expected future increase in value. As a result, the demand for investment property increases along with rising prices based on the market participants' expectations of prospective gains, which is not coherent with the right of demand. On the other hand, real estate is also purchased exclusively for its use. In such cases, a significant group of purchasers includes private persons who do not deal with professional transactions but acquire property for their own use. While investment property purchases are preceded by meticulous effectiveness calculations (BRYX and MATKOWSKI 2001; GAWRON 2011, FORYŚ and GDAKOWICZ 2005, WEBER 2014, EBRAHIM and HUSSAIN 2010), residential property purchases are often made by people who do not possess such skills. Not having knowledge of assessment methods 
more often leads to heuristic judgement than rational economic analysis (ŹRÓBEK-RÓŻAŃSKA 2016). Thus, people choose real estate which is not economically optimal, but most satisfying at the given moment. What is more, the decision-making process is dynamic, and the assessment of the particular elements of the entire subjective image of a given property can change. Therefore, actually bought real estate can differ significantly from that which had been previously preferred.

The above-mentioned deliberations led to the construction of two research hypotheses. In the first, it was assumed that there is a discrepancy between the preferences that potential purchasers revealed before making the final decision on buying residential real estate and the characteristics of actually purchased real estate. The first hypothesis was expanded by a second one, where it was assumed that this discrepancy results from compensation. The aim of the article was to verify these two hypotheses by comparing the revealed preferences with the actual trend of settlement.

\section{Data and Methods}

Current knowledge of behavioral economics allows for an understanding that the decision-making processes of purchasers are often coherent with compensation procedures, while information on the characteristics of a particular property is considered in comparison with an alternative solution (PAYNE and BETTMAN 2001). Heuristic models assume that non-professional purchasers generally use quite small sets of information that are relatively easy to access (BETSCH AND GLÖCKNER 2010; TIETZ 1992; TODD AND GIGERENZER 2000). Thus, the decision-making process more often leads to the most satisfying result rather than to the optimal one (BRYANT 2014), and satisfaction increases with the low cost of acquiring information, as non-professionals are sensitive to, e.g. the necessity to pay for information (BRÖDER 2000; NEWELL and SHANKS 2003), effort connected with gaining information, or searching their own memories (BRÖDER and SCHIFFER 2003; BRYANT 2007) and the amount of time spent on making the decision (RIESKAMP and HOFFRAGE 1999). In extreme cases, the need for simplification leads to such real estate buyers being inspired by other people's choices (Ho and CAMERER 1998; NAGEL 1995; LEDER et al. 2015). For residential real estate, this would lead to the chosen real estate being located in the most popular location and characterized by features that would most likely appeal to the majority. In the other cases, assuming greater autonomy of the potential real estate purchasers, the decision-making strategy would be more complex. According to the additive rule, a potential purchaser sums up the values of the characteristics of various localizations and real estates and chooses the option that achieves the highest final score. This rule allows for compensating some characteristics with the others.

Basing on the above presented knowledge on the decision-making psychology, the verification of the hypotheses proceeded in the following steps:

1. First, the analysis of the preferences of potential purchasers in terms of the localization of suburban plots for single-family houses (age groups of respondents: 25 and 26-40).

2. Second, the analysis of the real trend of settlement in the suburban zone. The aim was to recognize the characteristics of the localizations of real estates that were the objects of actually completed transactions.

3. Finally, the comparison of both analyses with special attention paid to compensation.

A group of 164 potential purchasers of building plots located in the suburban zone (within the certain age range) was chosen for the research. This choice resulted from the fact that migrations from the city toward suburban rural areas are currently common in Poland (ROSNER 2014; FRENKEL 2011; KAJDANEK 2012; KOWALEWSKI et al. 2014; ŻRÓBEK-RÓŻAŃSKA and ZYSK 2015; ŹRÓBEK-RÓŻAŃSKA and ZADWORNY 2016; HEFFNER 2011), and the participants are usually people between the ages of 26 and 40 (MigRACJE...2014; TROJANEK 2013). To expand knowledge, a group of 25 year-olds was additionally examined, comprising 91 people with relatively little experience, highly mobile and on the verge of making the decision of choosing their first own real estate. The research was conducted with the use of a questionnaire ${ }^{1}$, where respondents assessed the importance of 15 characteristics $^{2}$ of suburban residential real estate that they would like to purchase. Assessment was carried out on a scale from 0

\footnotetext{
1 Survey was conducted by A.Źróbek-Różańska, E. Zysk and A.Źróbek-Sokolnik

2 Characteristics were chosen based on the synthetic analysis of relevant literature (BRYANT et al. 1982; MCFADDEN 1997; Claval 2005; De Palma et al. 2005; ZondaG and Pieters 2005; Charmes 2009; KaŁuŻa, 2010; PaGliara et al. 2010; BIJKER et al. 2012; ROSNER 2014; ROTHWELL et al. 2015) and reports (DIAGNOZA PRZYCZYN...2010; MOBILNOŚĆ...2011, MigRACJE...2014).
} 
to 3, where 0 meant "unimportant" and 3 - "very important". Then, based on the results, the impact indicator was calculated with the use of the following formula (KARASZEWSKI and SUDOE, 1997, pp. 1718).

$$
W=\frac{\sum_{i=1}^{k} n_{1} w_{1}}{k * N}
$$

where: $\mathrm{W}$ - impact indicator, $i=$ assessment index, $n$ - number of answers for a particular factor in $i$ place, $k$ - maximum assessment from 1 to $k, N$ - number of respondents, $w$-assessment proper for the place of factor $i$.

The results of own studies were compared with results recreated and transformed to the same form of the impact indicator, achieved by other scientists (ŹRÓBEK et al. 2015, TROJANEK 2009). Then, the real trend of suburban settlement was analyzed on the example of particular villages located within the communes surrounding Olsztyn (own studies) and Kalisz (RĄCKA 2015), with the most important characteristics of these localizations highlighted. Finally, the results achieved through both analyses were compared and compensation was described. For the presentation, the weighted additive rule (WADD) was applied according to the M. Fishbein's formula (HOLBROOK and HULBERT, 1975, pp. 375-388):

$$
\mathrm{A}=\sum_{i=1}^{n} w_{i} v_{i}
$$

where: A - total assessment, wi - weight adequate for the $i$ characteristic, $v i$ - value adequate for the $i$ characteristic.

\section{Empirical Results}

Preferences as to desirable residential real estate located in the suburban zone revealed by respondents aged 26-40 were as follows: the most important characteristics were low price, lack of burdensome objects in the neighborhood (emitting air pollution, noise or unpleasant smells) and the access to the all media (full utilities). Next, potential purchasers claimed to be seeking real estate located in an esthetic place, from where there would be a convenient transport connection with the neighboring city and where they would feel safe (neighbors, street lights, pavements, etc.). The smallest importance was prescribed to the watering places, recreational infrastructure and inhabitants characterized by similar levels of income of (Fig. 1.).

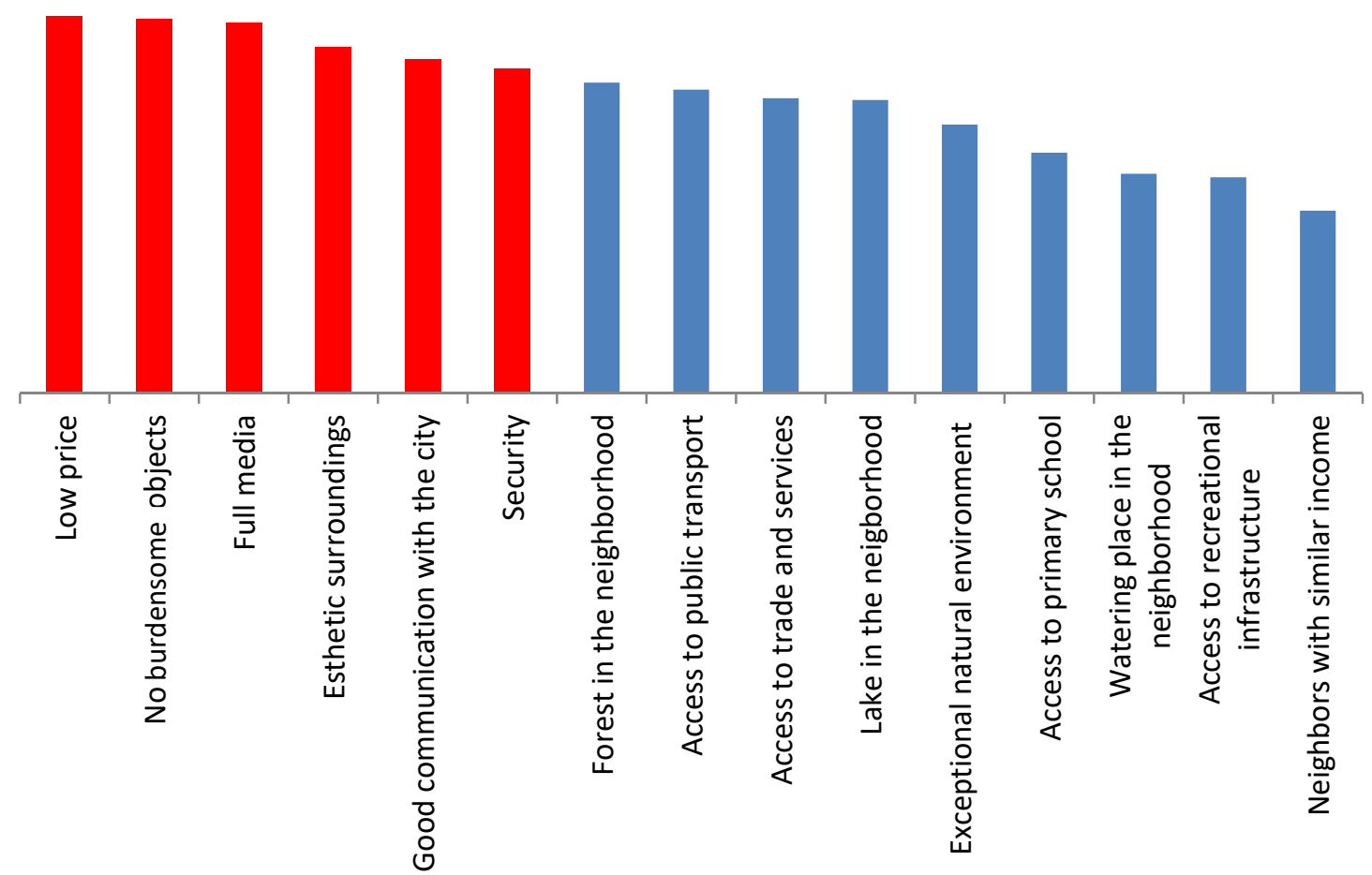

Fig. 1. Impact indicator calculated for answers revealed by the group 26-40 year-olds. Source: Own study. 
Similar results were achieved in the group of 25 year-olds. The most desirable characteristics were: full media, low price, security, lack of burdensome objects in the neighborhood and good transport communication with the city (impact indicator above 0.8 ), while the least importance was given to the exceptional natural environment, similar level of income and the proximity of watering places (Fig. 2.).

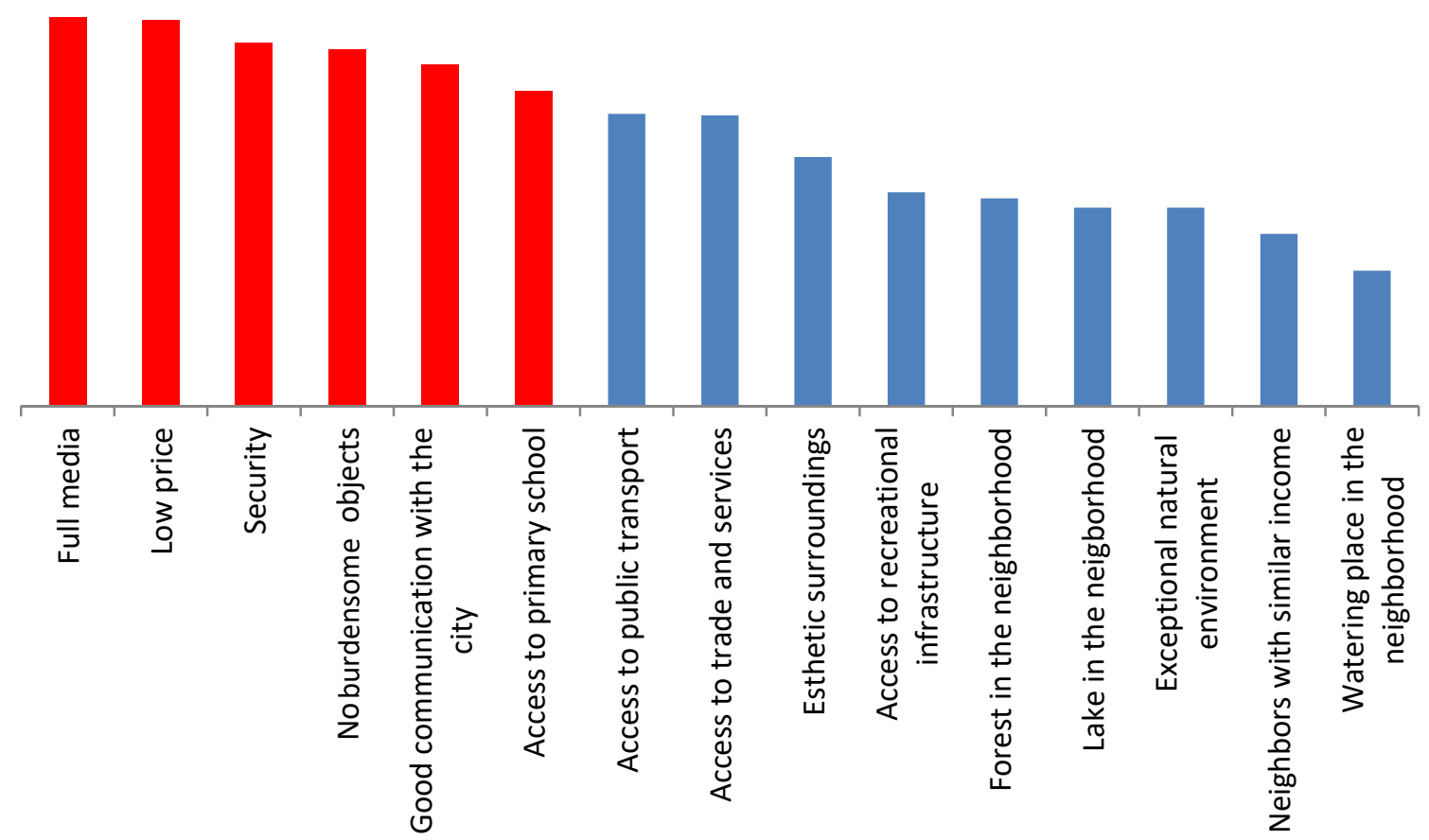

Fig. 2. Impact indicators calculated for answers provided by the group of 25 year-olds. Source: Own studies.

The achieved results were analogous to the results obtained by other scientists studying preferences toward residential real estate. Similar research was conducted by the team of scientists from Olsztyn and Poznań on a sample of 269 people inhabiting 3 Polish provinces: Śląskie, Warmińsko-Mazurskie and Wielkopolskie (ŹRÓBEK et al. 2015). The significant majority of respondents $(74 \%)$ was between the ages of 21 and 35. This group most valued the low price of real estate, the lack of burdensome objects in the neighborhood and security in the particular localization (Fig. 3.).

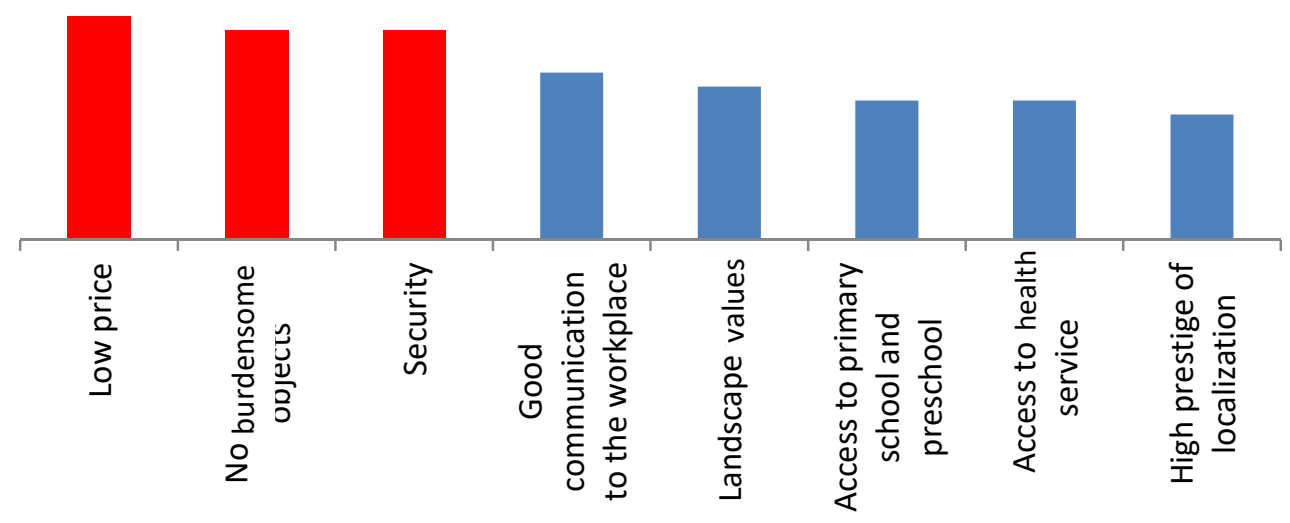

Fig. 3. Impact indicators calculated for answers provided by the group of 21-35 year-olds. Source: Own calculations based on data from ŹRÓBEK et al. 2015.

Similar results were achieved in Poznań (TROJANEK 2009) for a group of 120 people, among whom 
$75 \%$ were between the ages of 20 and 35 years. Those respondents attached the highest importance to low real estate price, good transport communication, attractive green areas and security (Fig. 4.)

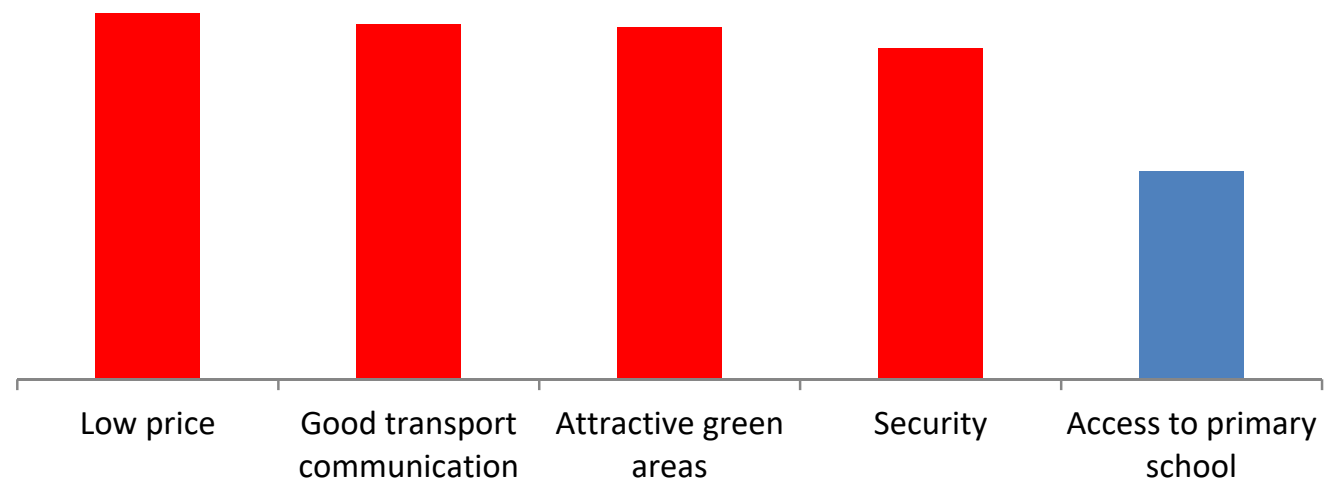

Fig. 4. Impact indicators calculated for answers provided by a group of 20-35 year-olds. Source: Own calculations based on data from TROJANEK 2009.

From the above-presented results, a subset of 5 characteristics which achieved the highest scores emerged. On the basis of data from the Main Statistical Office of Poland and data gained from the communes' offices, sample suburban villages located near the city of Olsztyn were selected. Such localizations were the most attractive for residential purposes, as expressed by the dynamic increase in the number of new inhabitants. Each village was assessed according to the 5 selected characteristics. For comparison, observations from the suburbs of Kalisz (RĄCKA 2015) were added and assessed (Tab.1.).

Table 1

Selected characteristics of suburban villages

\begin{tabular}{lllllc}
\hline Village & Price & Burdensome objects & $\begin{array}{c}\text { Transport } \\
\text { communication } \\
\text { with city }\end{array}$ & Security & $\begin{array}{c}\text { Access } \\
\text { to } \\
\text { media }\end{array}$ \\
\hline Dywity & High & $\begin{array}{l}\text { Chicken farm, sewage } \\
\text { treatment plant }\end{array}$ & Very good & High & Good \\
\hline Kieźliny & High & $\begin{array}{l}\text { Animal feed production } \\
\text { facility Wipasz }\end{array}$ & Very good & High & Good \\
\hline Eugwałd & High & Gravel pit & Very good & High & Good \\
\hline Spręcowo & High & National road & Very good & High & Good \\
\hline Stawiguda & High & Expressway & Very good & High & Good \\
\hline Tomaszkowo & High & Expressway & Very good & High & Good \\
\hline Dorotowo & High & Expressway & Very good & High & Good \\
\hline Bartąg & High & Crowded district & Very good & High & Good \\
\hline Gryźliny & High & Local airport & Very good & High & Good \\
\hline
\end{tabular}




\begin{tabular}{|c|c|c|c|c|c|}
\hline \multicolumn{6}{|c|}{ Kalisz suburbs: } \\
\hline Wolica & High & Hospital & Very good & High & Good \\
\hline Szałe & High & Tourism & Very good & High & Good \\
\hline Pruszków & High & Agricultural village & Very good & High & Good \\
\hline Zduny & High & $\begin{array}{l}\text { Production } \\
\text { Nestle }\end{array}$ & Very good & High & Good \\
\hline Borek & High & Busy road, hospital & Very good & High & Good \\
\hline
\end{tabular}

Source: Own studies and calculations based on data from RĄCKA (2015).

All selected villages were characterized by high (as compared to other villages located in the suburbs of the same city) prices of real estate zoned for building. Moreover, each village was located in the direct neighborhood with burdensome objects, such as: noisy production facilities, a local airport, busy national roads, objects with intensified traffic (hospital, multi-family buildings or recreational facilities for tourists), or operating agricultural farms, which, besides noise, emit unpleasant smells connected with field fertilization or livestock production. On the other hand, all analyzed villages were well-communicated with the city (relatively small distance and good quality of roads enabled travel to work in an acceptable amount of time), high security (developed districts, good access to security services, street lights) and a sufficient level of access to media.

Compensation was presented through calculations with the WADD rule, adjusted for the real estate market. This required prescribing weights and assessments to each characteristic of real estate localization. Weights were derived from the impact indicators, and assessments were made on a scale of $0-3$ scale, with 3 being the highest score. As all analyzed villages achieved the same result, they were compiled in Table 2.

Table 2

Weights and assessments for the each characteristic

\begin{tabular}{lccccc}
\hline & Price & $\begin{array}{c}\text { Burdensome } \\
\text { objects }\end{array}$ & $\begin{array}{c}\text { Transport } \\
\text { communication } \\
\text { with city }\end{array}$ & Security & $\begin{array}{c}\text { Access to } \\
\text { media }\end{array}$ \\
\hline $\begin{array}{l}\text { Weight for the } \\
\begin{array}{l}w \\
\text { characteristic }\end{array}\end{array}$ & 0.2120 & 0.2101 & 0.1874 & 0.1824 & 0.2081 \\
\hline $\begin{array}{l}\text { Assessment } \\
\text { for the } v \\
\text { characteristic }\end{array}$ & 1 & 1 & 3 & 3 & 3 \\
\hline
\end{tabular}

Source: Own calculations.

Weighted additive assessment for the studied villages was $\mathrm{A}=2.16$ and, thus, a very high score, with the exception of high real estate prices and the existence of burdensome objects (considered by respondents as key destimulants). It can, therefore, be stated that high assessments of three successive characteristics (in this case being: the transport communication with the city, security and media) can compensate low assessments of characteristics assumed as the most important (low price and lack of burdensome objects). For purposes of comparison, weighted addictive assessment was calculated for villages located at a larger distance from the city and without burdensome objects (located in the neighborhood of protected areas of the environment). Such localizations were characterized by attractive low process (Assessment 3) and the lack of burdensome objects in the vicinity (assessment 
3). Nevertheless, the greater distance worsened communication with the city (Assessment 1), as well as decreasing security (Assessment 1) and access to media (Assessment 1). In this case, the weighted additive assessment was $A=1.84$. Purchasers' choices should be directed towards localizations with the highest score, which, in this case, means the most popular, though at the same time expensive, villages.

\section{Discussion and Conclusions}

The real estate market is being ruled by a mechanism not coherent with the right of demand, because the greatest demand can be observed in the most expensive localizations. It can, therefore, be stated that particular localizations are expensive because they are popular and, at the same time, the demand is constantly increasing despite high prices. Moreover, a discrepancy between the set of characteristics describing real estate localization which emerges when looking at potential purchasers' preferences, and the set describing actually bought real estate can be observed on the real estate market. The surveyed groups of potential purchasers stated that the most important characteristics of residential real estate in the suburban zone are a relatively low price and the lack of burdensome objects in the neighborhood. In reality, however, the majority of new houses are being built in localizations where land properties are the most expensive (as compared to other localizations within the same commune) and with at least one burdensome object in the vicinity, e.g. busy and noisy national road. One explanation for this is the occurrence of compensation. High prices and burdensome objects are successfully compensated by other advantages, e.g. comfortable transport communication with the city or full access to media. Therefore, predicting the demand on the suburban residential real estate market should include compensation, while assessing the residential attractiveness of particular localizations requires taking into consideration several characteristics along with a set of proper weights attributed to them.

\section{References}

AleXANDeR E.R., 2015, Land-Property Markets and Planning: A special case, Land Use Policy, Vol. 41, November 2014, pp. 533-540.

BETSCH T., GLÖCKNER A., 2010, Intuition in Judgment and Decision Making: Extensive Thinking without Effort, Psychological Inquiry, Vol. 21/2010, pp. 279-294;

BIJKER R.A., HAARTSEN T., STRIJKER D., 2012, Migration to Less-Popular Rural Areas in the Netherlands: Exploring the Motivations, Journal of Rural Studies, No. 8 , pp. 490-498.

BRÖDER A., SCHIFFER S., 2003, Take the Best Versus Simultaneous Feature Matching: Probabilistic Inferences from Memory and Effects of Representation Format, Journal of Experimental Psychology: General, Vol. 132/2003, pp. 277-293.

BRÖDER A., 2000, Assessing the Empirical Validity of the "Take the Best" Heuristic as a Model of Human Probabilistic Inference, Journal of Experimental Psychology: Learning, Memory, and Cognition, vol. 26/2000, pp. 1332-1346.

Bryant C.R., Russwurm L.H., MCLELLAN A.G. 1982. The City's Countryside. Land and its Management in the Rural-Urban fringe. Longman, London and New York.

BRyANT D. J., 2007, Classifying Simulated Air Threats with Fast and Frugal Heuristics, Journal of Behavioral Decision Making, Vol. 20/2007, pp. 37-64.

BRYANT D.J., 2014, Strategy Selection in Cue-Based Decision Making, Canadian Journal of Experimental Psychology, Vol. 68, No. 2/2014, pp. 97-110.

BRYX M., MATKOWSKI R., 2001, Inwestycje w nieruchomości (Investements in Real Estate) [in Polish], Poltext, Warszawa.

CHARMES E., 2009, On the Residential 'Clubbisation' of French Periurban Municipalities, Urban Studies, SAGE Publications, 46(1)/2009, pp.189-212.

Claval P., 2005, Reading the Rural Landscapes, Landscape and Urban Planning, Vol. 70/2005, pp. 9-19.

de Palma A., Motamedi K., Picard N., Waddell P., 2005, A Model of Residential Location Choice with Endogenous Housing Prices and Traffic for the Paris Region, European Transport \Trasporti Europei Vol. 31.

EBRAHIM M.S., HuSSAIN S., 2010, Financial Development and Asset Valuation: The Special Case of Real Estate, Journal of Banking \& Finance 34 (2010), pp. 150-162

FORYŚ I., GDAKOWICZ A., 2005, Analiza efektywności inwestowania w nieruchomości komercyjne (Analysis of the Effectiveness of Investing in Commercial Real Estate) [in Polish], Studia i Materiały Towarzystwa 
Naukowego Nieruchomości (Studies and Materials of the Polish Real Estate Scientific Society), Vol. 13, No. 1.

FRENKEL I., 2011, Przemiany demograficzne na wsi w latach 2006-2009 (Demographic Changes in the Countryside in the Years 2006-2009) [in Polish], Wieś i Rolnictwo (Village and Agriculture) No. 1 (150), pp. 55-74.

GAWRON H., 2011, Metody oceny opłacalności inwestycji na rynku nieruchomości (Methods of Assessing Investment Profitability on the Real Estate Market) [in Polish], Wyd. UE Poznan (Poznań University of Economics Publishing).

Główny Urząd Statystyczny, 2014, Migracje wewnętrzne ludności. Narodowy Spis Powszechny Ludności i Mieszkań (Internal Migrations of the Population. National Population and Housing Census) [in Polish], Warszawa.

HEFFNER K., 2011, Semiurbanziacja a suburbanizacja. Ewolucja procesów w aglomeracji opolskiej (Semiurbanization vs. Suburbanization. The Evolution of Processes in the Opole Agglomeration) [in Polish\}, Studia Miejskie (Urban Studies), 3/2011, pp. 17-34.

Ho T.H., CAMERER C., 1998, Iterated Dominance and Iterated Best Response in Experimental "p-Beauty Contests", American Economic Review, No. 88/1998, pp. 947-969.

HolbrooK M. B., Hulbert J. M., 1975, Multi-Attribute Attitude Models: a Comparative Analysis, [in:] Schlinger M.J., Abor A. (eds.) Advances in Consumer Research, Vol. 02, Association for Consumer Research, pp. 375-388.

KAJDANEK K. 2012, Suburbanizacja po polsku (Suburbanization the Polish Way) [in Polish], Wyd. Nomos (Nomos Publishing House).

KAŁUŻA D., 2010, Migracje wewnętrzne a poziom rozwoju społeczno-gospodarczego wybranych największych miast w Polsce (Internal Migrations and the Level of Socio-Economic Development in Selected Biggest Cities in Poland) [in Polish], Acta Universitatis Lodziensis Folia Oeconomica 237/2010.

KARASZEWSKI W., SUDOŁ S., 1997, Empirical Research on the Process of Transformation of Polish Companies in the Period of 1990-1995, Wyd. UMK w Toruniu (Nicolaus Copernicus University in Torun), Torun.

Konsorcjum profile - ARC Rynek i Opinia, Diagnoza przyczyn i motywów wewnętrznej i zagranicznej migracji zarobkowej, charakter mobilności regionalnej pracowników (Diagnosis of Causes and Motives Behind Internal and International Migration, Nature of the Regional Mobility of Workers) [in Polish] (raport cząstkowy z IV etapu projektu: Badanie rynku na potrzeby projektu "Od diagnozy do prognozy - potrzeby gospodarki a jakość kapitału ludzkiego w województwie świętokrzyskim", Priorytet VIII, Działania 8.1., Poddziałania 8.1.4. Programu Operacyjnego Kapitał Ludzki) (Partial Report of IV stage of the Project: Assessing the market for the needs of the project "From Diagnosis to Forecasting - Needs of the Economy vs. the Quality of Human Capital in Świętokrzyskie Province", VIII Priority, Task 8.1, Subtask 8.1.4 of Human Capital Operational Program), Fundacja CBOS, 2011 (CBOS Foundation, 2011). Mobilność i preferencje migracyjne Polaków (Mobility and Migration Preferences of Poles), Warszawa.

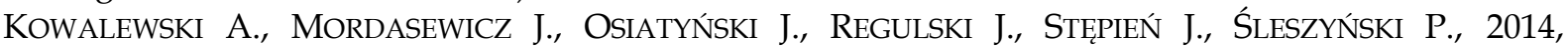
Ekonomiczne straty $i$ społeczne koszty niekontrolowanej urbanizacji w Polsce - wybrane fragmenty raportu (Economic Losses and Social Costs of Uncontrolled Urbanization in Poland - Selected Fragments of the Report) [in Polish], Samorząd Terytorialny (Local Self-Government) No. 4/2014, pp. 5-21.

Kucharska-Stasiak E., 2002, Nieruchomość a rynek (Real Estate and the Market), PWN.

LEDER J., HÄUSSER J.A., MOJZISCH A., 2015, Exploring the Underpinnings of Impaired Strategic decisionMaking under Stress, Journal of Economic Psychology, Vol. 49/2015, pp. 133-140.

MCFADDEN D., 1997, Modelling the Choice of Residential Location, [in:] Quigley J. (ed.) The Economics of Housing, Edwarg Elgar, London.

NAGEL R., 1995, Unraveling in Guessing Games: An Experimental Study, American Economic Review, Vol. 85/1995, pp. 1313-1326.

NeWEll B.R., SHANKS D. R., 2003, Take the Best or Look at the Rest? Factors Influencing "One-reason" Decision making, Journal of Experimental Psychology: Learning, Memory, and Cognition, Vol. 29/2003, pp. 53-65.

Pagliara F., Preston J., Simmonds D. (eds.), 2010, Residential Location Choice. Models and Applications, Springer Heidelberg Dordrecht, London New York. 
Payne J.W., Bettman J. R., 2001, Preferential Choice and Adaptive Strategy Use. [in:] Gigerenzer G., Selten R.(eds.) Bounded Rationality: The Adaptive Toolbox, MIT Press, Cambridge 2001, pp. 124-145.

RĄCKA I., 2015, Czynniki atrakcyjności nieruchomości mieszkaniowych na obszarach podmiejskich Kalisza (Attractiveness Factors of Residential Real Estate in the Suburban Areas of Kalisz) [in Polish], Problemy Rynku Nieruchomości (Problems of the Real Estate Market) Vol. 2/2015, pp. $29-37$.

Rieskamp J., Hoffrage U., 1999, When do People Use Simple Heuristics, and How Can we Tell? [in:] Gigerenzer G., Todd P. M. (eds.) Simple Heuristics that Make us Smart, Oxford University Press, Oxford 1999, pp. 141-167.

Rosner A., 2014, Migracje wewnętrzne i ich związek z przestrzennym zróżnicowaniem rozwoju społecznogospodarczego wsi (Internal Migrationa and their Relationship with the Spatial Differenciation of SocioEconomic Development of the Coutryside) [in Polish], Wieś i Rolnictwo (Village and Agriculture), No. 1 (162), pp. 63-79.

Rothwell A., Ridoutt B., Page G., Bellotti W., 2015, Feeding and Housing the Urban Population: Environmental Impacts at the Peri-Urban Interface under Different Land-Use Scenarios, Land Use Policy, Vol. 48, Nov. 2015, pp. 377-388.

TIETZ R., 1992, Semi-Normative Theories Based on Bounded Rationality, Journal of Economic Psychology, Vol. 13/1992, pp. 297-314.

Todd P. M, Gigerenzer G., 2000, Précis of Simple Heuristics that Make us Smart, Behavioral and Brain Sciences, Vol. 23/2000, pp. 727-741.

TROJAneK M., 2009, Preferencje nabywców na pierwotnym rynku mieszkaniowym w Poznaniu (Buyer's Preferences on the Primary Market in Poznan) [in Polish], Acta Sci. Pol., Administratio Locorum 8(1) 2009, pp. 5-19.

TrojaneK M., 2013, Customer Behaviour Patterns on the Primary Housing Market in Poznan in the Period 2010-2011, Real Estate Management and Valuation, Vol. 21, No. 4, pp. 47-53.

WEBER T.A., 2014, On the (Non-)Equivalence of IRR and NPV, Journal of Mathematical Economics, Vol. 52, 2014, pp. 25-39.

ZONDAG B., PIETERS M., 2005, Influence of Accessibility on Residential Location Choice, Transportation Research Record Journal of the Transportation Research Board, August 2005.

ŹróbeK S., TROJANEK M., ŹRÓBeK-SOKOLNIK A., TROJANEK R., 2015, The Influence of Environmental Factors on Property Buyers' choice of Residential Location in Poland, Journal of International Studies, Vol. 7, No. 3, 2015, pp. 163-173.

ŹRÓBEK-RÓŻAŃSKA A., 2016, Proces decyzyjny na rynku nieruchomości na przykładzie zakupu działki pod budowe wtasnego domu (Decision-Making Process on the Real Estate Market on the Example of Purchasing a Land Property for the Construction of a House) [in Polish], Świat Nieruchomości (World of Real Estate), Vol. 1(95)/2016, pp. 11-15.

ŹRÓBEK-RÓŻAŃSKA A., ZADWORNY D., 2016, Can Urban Sprawl Lead to Urban People Governing Areas? Evidence from the Dywity Commune, Poland, Cities, Vol. 59 (2016), pp. 57-65.

ŹRÓBEK-RÓŻAŃSKA A., ZYSK E., 2015, Czy rozlewające się miasto odmładza podmiejska wieś? Studium podolsztyńskich gmin wiejskich (Does Urban Sprawl Rejuvenate the Suburban Village? Study of Rural communes Neighboring the City of Olsztyn) [in Polish], Wieś i Rolnictwo (Village and Countryside), Vol. 4(169), pp. 123-139. 